\title{
«БАГРАТИОНОВЫ ВОЛКИ»: ЧЕРНИГОВСКИЙ КАВАЛЕРИЙСКИЙ ПОЛК ОТ ПОЛТАВЫ ДО МУКДЕНА
}

\author{
А. Б. Гуларян \\ (Орловский государственный аграрный университет им. Н. В. Парахина)
}

Аннотация: В статье восстановлена история Черниговского кавалерийского полка, в который входили два разных соединения, существовавшие в различное время, с интервалом в 60 лет. Но новый Черниговский полк, история которого связана с городом Орлом, свято хранил память о предшественниках, героях Полтавы и Отечественной войны 1812 г., со-блюдая традиционную для русской армии преемственность.

Подготовлено на основе доклада автора на Всероссийской научной конференции «Военная история России», которая прошла в Московском гуманитарном университете 25 апреля 20162.

Ключевые слова: история войн; Полтава; Рымник; Фокшаны; Шенграбен; Бородино; Кацббах; Лаоян; Мукден; георгиевские награды; военные традиции; ди-настия Романовых; история России

\section{«BAGRATION'S WOLVES»: THE CHERNIGOV CAVALRY REGIMENT FROM POLTAVA TO MUKDEN}

\author{
A. B. Gularyan \\ (N. V. Parakhin Oryol State Agrarian University)
}

Abstract: The article traces the history of the Chernigov cavalry regiment, which existed as two different entities within the space of 60 years. The new Chernigov regiment, with its historic ties to the city of Oryol, preserved the memories of the previous generations - of the heroes of Poltava and the Russian-French war of 1812, in line with the continuity typical for the Russian army.

This article is based on the paper presented at "The military history of Russia" conference, which was held at Moscow University for the Humanities on April 25, 2016.

Keywords: history of warfare; battles; Battle of Poltava; Battle of Râmnic; Battle of Focșani; Battle of Schöngrabern; Battle of Moscow (Borodino); Battle of Katzbach; Battle of Liaoyang; Battle of Mukden (Shenyang); Cross of St. George; military traditions; Romanov dynasty 
Черниговский полк вел свое начало от сформированного в 1668 г. гетманом Малороссии Демьяном Игнатьевичем Многогрешным Компанейского охотного полка. Слово «охотный» означало добровольность при формировании полка, а «компанейский» - указывало на иррегулярность полка и на право казаков самим выбирать командиров. Первые компанейские полки именовались не по месту формирования, а по полковнику - утверждаемому гетманом командиру полка. Название «Черниговский» возникло позднее, и полной уверенности, что в 1668 г. возник именно тот полк, у историков нет. Однако в 1898 г. было высочайше утверждено старшинство полка с 1668 года. (Государственный архив Орловской области - далее ГАОО. Ф. 711. Оп. 1. Д. 4. Л. 1-8.) Таким образом признавалось, что Черниговский драгунский полк старше Первой бригады российской Лейб-гвардии. В этом нет ничего удивительного: многие полки, сформированные в XVII в. на Украине из полурегулярных казачьих формирований - Киевский, Харьковский, Глуховский - также считались старше регулярных частей, сформированных в петровскую эпоху. Но никаких преимуществ перед Лейб-гвардией им это не давало.

Служба в «компанейских охотноконных» полках была многотрудной. Охотные казаки жили в постоянных столкновениях с турками и татарами, в разведке и конвойной службе. При Мазепе число таких полков было увеличено до семи, однако после измены гетмана они были расформированы, за исключением трех, оставшихся верными России. Эти полки получили территориальные наименования - Черниговский, Киевский и Северский. Командир Черниговского полка полковник Андрей Денисович Колбаса ходил с полком в атаку на шведов под Полтавой, участвовал в осаде Очакова, и после атаки на Русскую косу взял в плен 300 человек изменников-казаков, за что Петр I приказал ему самому выбрать себе награду (ГАОО. Ф. 305. ОП. 1. Д. 4. Л. 59-60.).

Переформированный в 1775 г. в легкоконный, названный в 1784 г. карабинерным, в 1796 г. кирасирским, а в 1801 г.драгунским, Черниговский кавалерийский полк принимает участие в сражениях при Рымнике и Фокшанах, во время польской кампании полк участвовал в бое под Брест-Литовском, где был разгромлен корпус польского генерала Сераковского. В славное суворовское время командовал полком бригадир Ермолай Поливанов.

В эпоху наполеоновских войн Черниговский драгунский полк участвовал в составе Русской армии в войне 1805 г. на территории Австрийской империи. Третья антинаполеоновская коалиция ставила своей целью освобождение от французов Германии, Ганновера, Италии, Голландии и Швейцарии и утверждение в Европе порядка, гарантирующего в будущем неприкосновенность границ европейских монархий. Но этим планам не дано было сбыться: Наполеон разгромил под Ульмом австрийскую армию 
генерала Мака и 13 ноября 1805 г. вступил в Вену. Австрийский император и его двор бежали.

Своими действиями австрийское командование поставило Русскую армию под командованием М. И. Кутузова в труднейшее положение. Кутузову стало ясно, что единственным выходом из создавшегося положения может быть только отвод войск из района Браунау, для соединения с подходившими из России войсками Буксгевдена. Разрушив переправы через реку Инн, оставив Браунау, русские войска начали труднейший маневр к Ольмюцу в Моравии. После переправы через Дунай русские войска дали бой французам у Кремса и Шенграбина, где отличился в арьергардных боях будущий герой Отечественной войны 1812 г. генерал Петр Багратион. Багратион должен был пожертвовать собой и своим отрядом и дать возможность армии Русской армии отойти. В отряд Багратиона входили полки: Киевский гренадерский, Подольский и Азовский мушкетерские, Павлоградский и Гессен-Гамбурский гусарские, Черниговский драгунский, один батальон Новгородского и один батальон Нарвского мушкетерского полка. Отряд с честью справился с поставленной перед ним задачей. Кутузов назвал Шенграбинский отряд «дружиной героев». За этот бой Черни-говский драгунский полк получил полковой георгиевский штандарт с надписью: «За подвиг при Шенграбине 4-го ноября 1805 года в сражении 5000 корпуса с 30000 неприятелем». Во время Отечественной войны 1812 г. командир полка майор Мусин-Пушкин, офицеры и рядовые также не раз были отмечены в приказах по 2-й русской армии генерала Багратиона. «Багратионовыми волками» называл черниговцев маршал Мюрат. В Бородинском сражении Черниговский полк участвовал в обороне Шевардинского редута (драгуны поддержали с фланга атаку 2-й кирасирской дивизии, во время которой был полностью истреблен 111-й линейный полк французской армии) и в бою за Семеновские флеши.

Переформированный в конце 1812 г. в конно-егерский, Черниговский полк участвовал и в заграничном походе русской армии. За действия во время битвы под Кацбахом полк получил 13 серебряных георгиевских труб с надписью: «Черниговскому конно-егерскому полку за отличие против неприятеля в сражении у Кацбаха 14 августа 1813 года». После окончания заграничного похода Русской армии Черниговский конноегерский полк просуществовал еще двадцать лет, до 1833 г., после чего был расформирован в числе прочих конно-егерских полков. К знаменитым кровавым событиям января 1826 г. черниговские кавалеристы не имеют никакого отношения: в восстании декабристов принимал участие Черниговский пехотный полк.

При расформировании полка все его реликвии - георгиевский штандарт, серебряные трубы и полковая икона Покрова Пресвятой Богороди- 
цы были переданы вместе с эскадронами в другие части Русской армии Каргопольский драгунский и гусарский принца Оранского полки, а потом были сосредоточены в 16-м драгунском Глуховском полку (кроме полковой иконы, которая находилась в 21-м драгунском Белорусском полку). Так закончилась история старого Черниговского полка. История этого полка никак не пересекалась с городом Орлом. Полк был расквартирован в городе Березна Черниговской губернии, где еще до революции не осталось ни одного старого здания, связанного с историей Черниговского полка, в том числе, была разобрана за ветхостью деревянная полковая церковь Чер-ниговцев (ГАОО. Ф. 305, ОП. 1, Д. 4, Л. 104.).

28 сентября 1896 г. в город Орел прибыл первый эскадрон вновь созданного высочайшим повелением 51-го драгунского Черниговского полка. Орел был определен местом формирования и расквартирования полка. С этого времени и до 1914 года история Орла, и история Черниговского полка тесно связаны между собой (ГАОО. Ф. 305, Оп.1, Д. 4, Л.2.).

Новый полк формировался из эскадронов, выделенных из 21-го Белорусского и 16-го Глуховского драгунских полков. Вместе с ними вернулись в полк и старинные реликвии - штандарт, трубы, икона. Эта икона Покрова Пресвятой Богородицы была «сооружена», как говорили в старину, в 1820 г. 5-м эскадроном черниговских конных егерей - капитаном Чайковским и рядовыми чинами. Первый праздник возрожденного полка состоялся 77 лет спустя, в октябре 1897 г., на праздник Покрова. В этом совпадении увидели Знамение и Помысел Божий.

Как уже говорилось выше, старшинство нового полка было определено с момента формирования старого Черниговского «компанейского охотноконного». Этому способствовало ходатайство командира полка, полковника Афанасия Андреевича Цурикова, который стремился возродить старые традиции прежнего полка. Это было особенно актуально в общественных условиях того времени. Дело в том, что при проведении милютинской военной реформы русские генералы находились под большим влиянием опыта военных действий гражданской войны между Севером и Югом Северо-Американских Соединенных Штатов и Франкопрусской войны. В частности, существовавшие в армии кавалерийские части переводились в драгуны (что объясняет большую цифру номера Черниговского полка). Именно драгунские части, одинаково обученные действовать как в конном, так и в пешем строю, показали себя наиболее эффективными в американской гражданской войне. Но решение перевести всю кавалерию в драгуны имело как минимум два отрицательных последствия. Во-первых, американская легкая кавалерия была эффективна в условиях полурегулярной гражданской войны и в столкновениях с индейцами; но регулярным, профессионально обученным частям европей- 
ских армий она явно уступала. Во-вторых, при проведении этой реформы терялись традиции и бесценный опыт военный практики, передававшиеся в русских войсках из поколения в поколение. Поэтому инициатива А.А.Цурикова имела важное для дальнейшей судьбы полка значение.

За время существования полк сменил шесть командиров - А. А. Цурикова, В. С. Зенкевича, А. И. фон Кауфмана, князя Н. В. Урусова, великого князя Михаила Александровича и Н. С. Блохина.

Черниговский полк имел своего шефа из императорской фамилии Великую княгиню Елизавету Федоровну, сестру последней русской императрицы. Сейчас она более известна как покровитель Марфо-Мариинской общины сестер милосердия. Шефство Елизаветы Федоровны над полком было очень деятельным: был оборудован первоклассный госпиталь, обязательная по тем временам походная полковая церковь, на маньчжурском фронте солдаты получали от Великой княгини праздничные подарки.

В качестве полкового священника А. А. Цуриков пригласил отца Митрофана Сребрянского, бывшего до этого настоятелем Двинского крепостного собора. В Орле отец Митрофан устроил церковь Черниговского полка в честь Покрова Святой Богородицы, а при церкви - школу на средства прихожан и почитателей. Благодаря ему была возведена и железнодорожная церковь Иверской иконы Божьей Матери, сохранившаяся в настоящее время. Сборы средств на ее сооружение производились на молебнах отца Митрофана. Впоследствии он служил священником в московской МарфоМариинской обители. И это не случайно: во время одного из визитов в Орел Елизавета Федоровна присмотрелась к отцу Митрофану, и решила, что это и есть тот духовный пастырь, который нужен Марфо-Мариинской обители. С большим трудом ей удалось уговорить Митрофана Сребрянского оставить службу в Орле и переехать в Москву.

Под штаб полка и офицерское собрание был отведен городской дом на Московской улице - бывший дом орловского дворянина Перелыгина, который был заложен в 1658 г. С этим домом связаны банкротства двух банков - в конце XIX в. в нем располагался разорившийся Орловский коммерческий банк, а в конце XX в. там же разорился банк «Ока».

C военными постояльцами дому Перелыгина повезло больше. Особы из царской фамилии были частыми гостями в полковом офицерском собрании. Так 6 мая 1904 г. ( по ст. стилю) отец Митрофан совершал службу в присутствии последнего русского императора Николая II, его брата, Великого князя Михаила, и дяди царя, московского генерал-губернатора Великого князя Сергея Александровича, мужа Елизаветы Федоровны (Сребрянский, 1912: 268). Отстояв службу в Покровской церкви, император лично благословил полк иконой в объявленный перед этим маньчжурский поход (Памятная книжка, 1904). 
На фронт Русско-японской войны полк отбыл 11 июня 1904 г. (ст. стиль) во главе с командиром, полковником В. С. Зенкевичем. Провожал его весь Орел. 17 июля Черниговский полк прибыл к театру военных действий под Ляоян, и был приписан к 2-й отдельной бригаде 17-го армейского корпуса (командующий - генерал Н. В. Степанов). Как отдельное соединение полк во время кампании не использовался, а действовал в составе бригады совместно с 52-м драгунским Нежинским полком, а также в составе других крупных кавалерийских соединений.

Служба полка заключалась в разведке и заграждении. На практике это означало постоянно находиться на передовой, постоянную боевую готовность. Первая серьезная стычка произошла 15 августа 1904 г. (ст. стиль) между 6-м эскадроном Черниговского полка, несшим дозорную службу, и двумя ротами японской пехоты. Пять солдат было убито, четыре ранено и еще четверо пропали без вести. С этого времени стычки не прекращались, потери росли. Несмотря на этот полк с честью нес передовую службу. При ведении разведки отличились офицеры Калинин, Залесский, Гольдгаар, Свидерский, Тимофеев, Пантелеев. Особо же отличился унтерофицер Власов - он добровольно ходил в разведку, много раз пробирался в расположение японских войск и вел наблюдение за их позициями. Он был награжден Георгиевским крестом 4-й степени и был представлен к Георгию 3-й степени.

Еще один подвиг солдата Черниговского полка подробно описан в дневнике отца Митрофана Сребрянского. Рядовой Раскопатин попал в плен во время стычки 15 августа 1904 г., когда под ним убили лошадь. Десять дней он провел в плену, пока не удалось бежать. Неделю он блуждал по полям, питаясь сырым гаоляном и утоляя жажду из луж, пока китайцы не вывели его к линии фронта. Раскопатина произвели в унтер-офицеры и представили к Георгиевскому кресту. Главнокомандующий Куропаткин лично приколол награду на грудь героя во время смотра 3 ноября 1904 г. На 27 сентября 1904 г. в Черниговском драгунском полку было 14 георгиевских кавалеров.

Но, не смотря на весь героизм солдат и офицеров, благодаря бездарности и нерешительности командования, отсутствию крепкого тыла, русская армия отступила сначала от Лаояна, потом с реки Шахе, наконец, от Мукдена. Все это рождало недовольство и недоумение солдат и офицеров, не проигравших явно ни одного сражения. В дневнике отца Митрофана появляются строчки: «Спасать, спасать нам нужно честь России! Я представить себе не могу положения нашего государства в случае неудачи здесь. Не говоря уже лично за себя и каждого из военных. Уж лучше останусь служить в Сибири, чем с позором вернусь домой» (Сребрянский, 1912: 212). 
Среди русского командования были и решительные генералы. Один из них - Павел Иванович Мищенко - предложил рейд в глубокий тыл японцев, на Инкоу. Для этой цели были собраны все кавалерийские соединения армии, что позволило сформировать три колонны. 2-я отдельная бригада Н. В. Степанова вошла в третью колонну, возглавляемую генералом Самсоновым. Однако этот поход, начатый 25 декабря 1904 года (ст. стиль), провалился. Инкоу не был взят, хотя и подожжен артиллерией. Главная причина - использование японцами пулеметов для обороны Инкоу. Черниговский полк потерял в этом деле одного офицера, четырех солдат убитыми и восьмерых пропавшими без вести. Пятнадцать солдат было ранено. Вернувшись из похода, черниговцы узнали о начавшейся в России революции.

После отступления русской армии на границу внутренней Монголии и до заключения мирного договора Черниговский драгунский полк в составе отряда кавалерии генерала Грекова несет службу на аванпостах перед армией. Вся армия была прикрыта завесой из кавалерии. Грекову достался для прикрытия четырехугольник вокруг города Чженцзятунь 70 верст на север, 50 верст на юг, 30 - на восток и 20 - на запад. Эту территорию «держали» 12 эскадронов и конная батарея, выделяя ежедневно в службу половину отряда. Один эскадрон нес боевое охранение города, еще один держал границу Монголии и северный фланг отряда. Один эскадрон держал летучую почту до штаба корпуса, два уходили на юг в разведку, еще половина эскадрона уходила в горы, пока вторая половина занималась заготовкой скота. Такую службу нельзя назвать легкой. Зато армия могла спать спокойно.

Остается добавить, что, к чести России, регулярная русская армия, несмотря на все неудачи, продолжала стоять твердо, готовая к бою. Но боя не было. После ратификации мирного договора Черниговский полк погрузился 3 мая 1906 г. в эшелоны и 2 июня прибыл в Орел. Можно сказать словами отца Митрофана: «Слава Богу, помогшему благополучно совершить тяжкий и опасный поход».

Признание же заслуг Черниговского полка во время Русско-японской войны со стороны Николая II задержалось на три года. Только 1 октября 1909 г. из Ливадии была получена высочайшая телеграмма следующего содержания: «Передайте славным черниговским гусарам мою благодарность за их преданность и доблесть в минувшую кампанию. Николай» (ГАОО. Ф. 305. ОП. 1. Д. 3, Л. 13). 51-й драгунский Черниговский полк был в это время переименован в 17-й гусарский. В качестве особой монаршей милости Николай II назначил 16 мая 1909 г. (ст. стиль) командиром полка своего брата, Великого князя Михаила Александровича. Эта милость, как и запоздалая телеграмма, очень походила на неудовольствие - Великий 
князь Михаил был в опале (ГАОО. Ф. 539. Оп. 1. Д. 110. Л. 3).

Формальным поводом для царского неудовольствия стал морганатический брак Михаила с графиней Н. С. Брасовой, урожденной Шереметьевской, по первому мужу Мамантовой по второму мужу - фон Вульферт. Фамилию Брасова она взяла по имению Михаила Александровича на Opловщине. Весть об этом браке скандализировала весь дом Романовых. Однако отношения между братьями и до этого были далеко не безоблачными. Во-первых, вдовствующая императрица Мария Федоровна не оставляла своих планов «рокировки на престоле». Она стремилась заменить «менее способного» к правлению сына «более способным». Во-вторых, уже было известно о тяжелой болезни наследника престола, цесаревича Алексея, при котором Михаил Александрович состоял «условным регентом», что весьма раздражало царствующую императрицу Александру Федоровну. Проштрафившегося «условного регента» решили убрать из Петербурга и из Лейб-гвардии. А так как в Орловской губернии находилось большое Брасовское имение, принадлежавшее Михаилу, выбор пал на Орел.

В Орле Великий князь Михаил жил в сохранившемся по настоящее время доме Лесковского на углу улиц Салтыкова-Щедрина и Красноармейской (бывшей Борисоглебской улицы и бывшего Зиновьевского переулка). К его приезду улица и переулок были заново замощены, возле дома поставлены фонари. В советское время он был более известен как дом, в котором после освобождения Орла останавливался генерал Родин.

Однако Брасовским имением и Черниговским полком связи Великого князя Михаила Александровича с Орлом не исчерпываются. Он был хорошо знаком с некоторыми дворянскими семьями Орловщины, например, Стаховичами. Род Стаховичей польского происхождения. В середине XVII в. шляхтич Федор Стахович вышел в Россию и записался в казаки. Его сын Андрей был уже городницким сотником. После измены Мазепы новым гетманом Украины был избран Скоропадский. Однако Петр I якобы сказал Андрею Стаховичу: «А гетманом-то следовало быть тебе». В 1819 г. полковник артиллерии Александр Иванович Стахович женился на елецкой дворянке Наталье Михайловне Перваго (род Перваго происходит от первого конюшего князя Василия Темного) и получил в качестве приданого имение Пальна Елецкого уезда. Оно стало родовым гнездом Стаховичей.

Один из Стаховичей - Михаил Александрович - с 1892 по 1895 г. избирается уездным Елецким, а с 1895 по 1907 гг. - Орловским губернским предводителем дворянства. На этой должности он способствовал развитию народного образования и земского самоуправления в губернии. Будучи либералом, М. А. Стахович принимал участие в деятельности кружка «Беседа» и в совещаниях земских деятелей, организованных Д. Н. Шиповым. М. А. Стахович и Д. Н. Шипов были вызваны к всесильному мини- 
стру внутренних дел В. К. Плеве, который пригрозил обоим отрешением от должностей. М. А .Стаховича спасло знакомство с Великим князем Михаилом Александровичем. Будучи представленным Великому князю в 1902 г. на курских маневрах, М. А. Стахович пригласил его в Орел на открытие сельскохозяйственной выставки, и Михаил это приглашение принял (Па-мятная книжка, 1904: 5). После чего Плеве не решился провести в жизнь свою угрозу.

Когда же в 1909 г. Великий князь Михаил Александрович был назначен полковым командиром, его непосредственным начальником стал другой Стахович, Павел Александрович, генерал-майор, с 1909 по 1912 г. командир 2-й отдельной кавалерийской бригады. П. А. Стахович также был примечательным человеком. В 1884 г. он закончил Пажеский корпус первым учеником, служил в Лейб-гвардии Кавалергардском полку, стал офицером Генерального штаба. Во время Англо-бурской войны 1899-1902 гг. был русским военным агентом при английской армии. Опубликована его записка: «Донесение генерального штаба полковника Стаховича, командированного на театр военных действий в Южной Африке 1899-1900». С 1900 г. П. А. Стахович командовал 52-м драгунским Нежинским полком, расквартированном в Ельце. Участвовал в Русско-японской войне, за битву при Лаояне награжден золотым оружием.

Великий князь Михаил Александрович прокомандовал Черниговским гусарским полком три года, проявив себя дельным военным. Будучи хорошим кавалеристом и прекрасным спортсменом, Великий князь Михаил выиграл ежегодный приз Стипль-Чез в конных скачках 1910 г. Он участвовал в учениях 2-й бригады под Калугой, под его руководством Черниговский гусарский полк был удостоен царской благодарности на смотре в Царском Селе в 1911 г. Примечательно, что сразу после этого смотра Михаил Александрович был отставлен от полка, и в скором времени вынужден был покинуть вместе с графиней Брасовой пределы Российской империи. Однако в память о командовании Черниговским полком Великий князь был назначен его новым шефом.

В 1912 г. в полк был призван рядовым Александр Васильевич Горбатов, будущий советский полководец и генерал, освободивший в 1943 г. Орел от немецких захватчиков. Именно в Черниговском полку А. В. Горбатов стал профессиональным кадровым военным, кавалеристом, с отличием провоевавшим в 1914-1917 гг. в составе полка на Юго-Западном фронте (Минаков, 1991).

Торжественные проводы полка на фронт русско-германской войны состоялись 13 июля 1914 г. (ст. стиль) в 12 часов дня на плацу Орловского кадетского корпуса. Был отслужен торжественный молебен за победу русского оружия. В память о пребывании в городе горожане преподнесли 
черниговским гусарам новую икону Покрова Пресвятой Богородицы, серебряную братину и приветственный адрес, подписанный гласными Городской думы. Полк, в свою очередь, подарил городу фотографии полка в полном составе. Никто не знал тогда, что полк уходит из Орла навсегда, а война закончится революцией.

На Юго-Западном фронте полк действовал в составе 13-го армейского корпуса, позднее - 17-й кавалерийской дивизии, участвовал в славном Брусиловском прорыве в мае 1916 г и разделил судьбу старой русской армии - был распущен в 1917 г. Новой власти старые традиции оказались не нужны...

\section{СПИСОК ЛИТЕРАТУРЫ}

Минаков, С. Т. (1991). Взвихренной Россией рожденный // Вече. № 3.

Памятная книжка и адрес-календарь Орловской губернии за 1904 год (1904). Отдел 5. Орел : типография Губернского Правления.

Сребрянский, М. В. (1912) Дневник из времен русско-японской войны священника 51 драгунского Черниговского Ее Императорского Высочества Великой Княгини Елизаветы Федоровны полка с момента отправления полка в Манчжурию 11 июня 1904 года и до возвращения в Орел 7 июня 1906 года. М. : Печатня А.И. Снегиревой.

Дата поступления: 15.06.2016 г.

Гуларян Артем Борисович - кандидат исторических наук, доцент кафедры гуманитарных дисциплин Орловского государственного аграрного университета им. Н. В. Парахина. Адрес: 302019, Россия, г. Орел, ул. Генерала Родина, д. 69. Тел.: +7 (4862) 70-18-87. Эл. адрес: agularyan@ yandex.ru

Gularyan Artem Borisovich, Candidate of History, Associate Professor, Department of theHumanities, N.V.Parakhin Oryol StateAgriculturalUniversity. Postal address: 69 General Rodin St., 302019 Oryol, Russian Federation. Tel.: +7 (4862) 70-18-87. Email: agularyan@yandex.ru 